(c) American Dairy Science Association, 2005.

\title{
Effects of Physically Effective Fiber on Intake, Chewing Activity, and Ruminal Acidosis for Dairy Cows Fed Diets Based on Corn Silage*
}

\author{
K. A. Beauchemin and W. Z. Yang \\ Agriculture and Agri-Food Canada, Research Centre, Lethbridge, AB, T1J 4B1, Canada
}

\begin{abstract}
A study was conducted to investigate the effects of physically effective (pe) neutral detergent fiber (NDF) content of dairy cow diets containing corn silage as the sole forage type on feed intake, meal patterns, chewing activity, and rumen $\mathrm{pH}$. The experiment was designed as a replicated $3 \times 3$ Latin square using 6 lactating dairy cows with ruminal cannulas. Diets were chemically similar but varied in peNDF content (high, medium, and low) by altering corn silage particle length. The physical effectiveness factors for the long (original), medium (rechopped once), and fine (rechopped twice) silages were determined using the Penn State Particle Separator and were $0.84,0.73$, and 0.67 , respectively. The peNDF contents of the diets were 11.5, 10.3, and $8.9 \%$, for the high, medium, and low diets, respectively. Increased forage particle length increased intake of peNDF but did not affect intake of DM or NDF. Number of chews (chews/d) and chewing time, including eating and ruminating time, were linearly increased with increasing dietary peNDF. Meal patterns were generally similar for all treatments, except that number of meals was quadratically increased with increasing dietary peNDF. Mean ruminal $\mathrm{pH}$, area between the curve and a horizontal line at $\mathrm{pH} 5.8$ or 5.5 , and time that $\mathrm{pH}$ was below 5.8 or 5.5 were not affected by peNDF content. Dietary peNDF content was moderately correlated to number of chews during eating $(r=0.41)$ and to total chewing time $(r=0.37)$. The present study demonstrates that increasing the peNDF content of diets increased chewing time, but increased chewing time did not necessarily reduce ruminal acidosis. Models that predict rumen $\mathrm{pH}$ should include both peNDF and fermentable OM intake. Dietary particle size, expressed as peNDF, was a reliable indicator of chewing activity. (Key words: physically effective NDF, chewing, rumen $\mathrm{pH}$, dairy cows)
\end{abstract}

Received September 16, 2004.

Accepted December 20, 2004.

Corresponding author: Karen A. Beauchemin; e-mail: beauchemin @agr.gc.ca.

*Contribution number: (387) 04054.
Abbreviation key: $\mathbf{C S}=$ corn silage, $\mathbf{F P L}=$ forage particle length, pef = physically effectiveness factor, peNDF $=$ physically effective NDF, $\mathbf{P S P S}=$ Penn State Particle Separator containing 2 sieves (19 and $8 \mathrm{~mm}$ ) and a pan, TCL $=$ theoretical cut length.

\section{INTRODUCTION}

Dairy cows require diets that contain adequate particle size to maintain healthy rumen function. Adequate particle length can be difficult to ensure because most commercial dairy rations contain high levels of concentrate and high quality silages that are often finely chopped. These types of diets are highly fermentable in the rumen and encourage maximum milk production; however, they can lead to a variety of metabolic disorders, including subclinical ruminal acidosis, reduced fiber digestion, milk fat depression, displaced abomasum, lameness, and fat cow syndrome (NRC, 2001). An important aspect of fiber nutrition is that cows consuming sufficient NDF without a sufficient proportion of long particles can exhibit the same metabolic disorders as cows consuming a diet deficient in chemical fiber (Fahey and Berger, 1988). However, current NRC (2001) recommendations do not account for the particle size of feeds due to the paucity of information.

The concept of physically effective fiber (peNDF) was introduced to account for the physical characteristics of NDF (primarily particle size) that affect chewing activity (saliva secretion). This concept is based on the hypothesis that the fiber in long feed particles $(>1 \mathrm{~cm})$ promotes chewing and saliva secretion, which helps neutralize the acids produced during ruminal digestion of feeds. The fiber that promotes chewing is considered physically effective. The peNDF content of the diet can be determined by multiplying the NDF content of the diet by its physical effectiveness factor (pef). Although various methods are available to measure particle size of diets, the Penn State Particle Separator (PSPS) has become widely accepted as a quick and practical method for routine use on farm to evaluate particle size of forages and TMR (Lammers et al., 1996). Using the PSPS, a particle distribution is determined from 3 fractions: proportion of particles retained on the $19.0-\mathrm{mm}$ sieve, proportion of particles that pass through the $19.0-\mathrm{mm}$ 
sieve but are retained on the $8.0-\mathrm{mm}$ sieve, and proportion of particles that pass through the $8.0-\mathrm{mm}$ sieve (Lammers et al., 1996). The pef (ranging from 0 to 1) is calculated as sum of the proportion of particles retained on both 19.0 and $8.0-\mathrm{mm}$ sieves.

Although a number of studies using the PSPS technology have been conducted in recent years to determine the effects of dietary peNDF on feed intake, chewing time, and ruminal $\mathrm{pH}$ (Yang et al., 2001; Krause et al., 2002; Beauchemin et al., 2003; Kononoff et al., 2003; Plaizier, 2004), the results obtained in these studies are not conclusive. In some studies, increasing intake of peNDF increased chewing activity but there was no effect on rumen $\mathrm{pH}$ for corn silage- (CS) (Kononoff et al., 2003) or for alfalfa haylage-based diets (Kononoff and Heinrichs, 2003a). Some studies (Yang et al., 2001; Kononoff and Heinrichs, 2003b) showed that peNDF was a poor predictor of chewing time and rumen $\mathrm{pH}$. In contrast, Beauchemin et al. (2003) reported that the peNDF was a reliable indicator of chewing activity and subclinical ruminal acidosis.

The objectives of the present study were to determine the effect of increasing the peNDF concentration of a diet containing $\mathrm{CS}$ on feed intake, chewing activity, and ruminal $\mathrm{pH}$ and fermentation in lactating dairy cows. The peNDF concentration of the diet was increased by using CS differing in particle length and the peNDF content of the diets was determined using the PSPS.

\section{MATERIALS AND METHODS}

\section{Corn Silage}

Corn silage used in the present study was obtained from a commercial dairy farm. Whole plant corn (hybrid 39T68, Pioneer Hi-Bred International, Des Moines, IA) was harvested at about $31 \%$ DM using a self-propelled forage harvester (model FX58; New Holland, New Holland, PA) set to obtain a 19.1-mm theoretical cut length (TCL) with kernel processing at a $2-\mathrm{mm}$ roll clearance. The chopped forage was placed as a silage stack, covered with black plastic, ensiled for approximately $4 \mathrm{mo}$, and designated long forage. The required amount of corn silage was transported every morning during the course of the experiment from the dairy farm to the Dairy Facility at the Lethbridge Research Centre. The experiment was conducted during the winter months during which time the ambient temperature remained below freezing, thus heating and aerobic stability of the silage were not deemed to be important confounding factors. Upon arrival at the Centre, a portion of the silage was rechopped using a small bedding chopper (2-E, W-W Grinder Corp, Wichita, KS) fitted with an 11-mm sieve to obtain silage of medium particle length. The medium particle length silage was rechopped a second time to
Table 1. Chemical composition and fermentation measures of corn silage. ${ }^{1}$

\begin{tabular}{lc}
\hline Item & \\
\hline Chemical & \\
DM, \% & 33.8 \\
CP, \% of DM & 9.0 \\
Soluble protein, \% of DM & 4.4 \\
Degradable protein, \% of CP & 74.3 \\
NDF, \% of DM & 45.8 \\
ADF, \% of DM & 30.5 \\
NFC, \% of DM & 35.0 \\
Ash, \% of DM & 7.2 \\
Total digestible nutrients, \% of DM & 66.8 \\
NE, Mcal/kg & 1.48 \\
Ca, \% of DM & 0.26 \\
P, \% of DM & 0.21 \\
Mg, \% of DM & 0.18 \\
K, \% of DM & 1.28 \\
Fermentation & \\
pH & 3.77 \\
Ammonia, \% of DM & 0.3 \\
Lactic acid, \% of DM & 4.5 \\
Acetic acid, \% of DM & 1.12 \\
Propionic acid, \% of DM & $<0.01$ \\
Isobutyric acid, \% of DM & $<0.01$ \\
Butyric acid, \% of DM & $<0.01$ \\
Total VFA, \% of DM & 5.62 \\
\hline
\end{tabular}

${ }^{1}$ Chemical composition and fermentation parameters were determined by Cumberland Valley Analytical Service, Inc. (Maugamsville, MD) using a single representative sample.

obtain silage of fine particle length. Thus, all 3 silages were from the same silage pile that was from the same field, harvested and ensiled on the same day. Chemical composition and fermentation parameters of the silage as sampled from the silo before starting the experiment are presented in Table 1 . These analyses were conducted commercially by Cumberland Valley Analytical Service, Inc. (Maugamsville, MD).

\section{Cows and Diets}

Six lactating Holstein cows were used in an experiment to investigate effects of peNDF content of CSbased diets on feed intake, eating patterns, chewing activity, and rumen $\mathrm{pH}$ and fermentation. The cows were fitted with ruminal cannulas and they averaged $622 \pm 84 \mathrm{~kg}$ of BW and $48 \pm 25 \mathrm{DIM}$, and were randomly assigned to a replicated $3 \times 3$ Latin square. The ruminal cannulas measured $10 \mathrm{~cm}$ in diameter and were constructed of soft plastic (Bar Diamond, Parma, ID). Cows were housed in individual tie stalls and offered a TMR 3 times daily at 0800,1500 , and $1800 \mathrm{~h}$ for ad libitum intake. Cows were cared for according to the Canadian Council on Animal Care Guidelines (Ottawa, ON, Canada).

Cows were offered 1 of 3 diets, which were chemically identical with approximately $58 \%$ of concentrate and 
Table 2. Ingredients and chemical composition of the total mixed diet (DM basis).

\begin{tabular}{|c|c|}
\hline Item & \\
\hline \multicolumn{2}{|l|}{ Ingredients, \% } \\
\hline Corn silage ${ }^{1}$ & 41.85 \\
\hline Barley grain, steam-rolled ${ }^{1}$ & 37.80 \\
\hline Corn gluten meal & 0.90 \\
\hline Heat-treated canola meal (Alberta Gold) & 5.86 \\
\hline Soybean meal & 9.92 \\
\hline Beet molasses & 0.68 \\
\hline Calcium carbonate & 0.63 \\
\hline Dicalcium phosphorus & 0.41 \\
\hline Vitamin-mineral mix ${ }^{2}$ & 1.13 \\
\hline Canola oil & 0.68 \\
\hline Binding agent (Aka) & 0.15 \\
\hline \multicolumn{2}{|l|}{ Chemical } \\
\hline $\mathrm{DM}, \%$ & 54.6 \\
\hline $\mathrm{OM}, \%$ of $\mathrm{DM}$ & 92.6 \\
\hline $\mathrm{CP}, \%$ of $\mathrm{DM}$ & 17.1 \\
\hline $\mathrm{NDF}, \%$ of DM & 32.6 \\
\hline NDF from forages, $\%$ of NDF & 61.5 \\
\hline $\mathrm{ADF}, \%$ of $\mathrm{DM}$ & 15.4 \\
\hline Starch, \% of DM & 34.8 \\
\hline $\mathrm{NE}_{\mathrm{L}}, \mathrm{Mcal} / \mathrm{kg}$ & 1.70 \\
\hline
\end{tabular}

${ }^{1}$ Chemical composition of corn silage and barley grain (DM basis) was 93.8 and $90.5 \%$ for OM; 46.5 and $23.2 \%$ for NDF; 26.6 and $6.3 \%$ for $\mathrm{ADF} ; 8.7$ and $11.3 \%$ for $\mathrm{CP}$, respectively.

${ }^{2}$ Contained $51.97 \% \mathrm{NaCl}, 35.98 \%$ Dynamate (Pitman Moore, Inc., Mundelein, IL; $18 \% \mathrm{~K}, 11 \% \mathrm{Mg}, 22 \% \mathrm{~S}, 1000 \mathrm{mg} \mathrm{Fe} / \mathrm{kg}), 2 \%$ $\mathrm{ZnSO}_{4} \cdot \mathrm{H}_{2} \mathrm{O}, 2.4 \% \mathrm{MnSO}_{4} \cdot 4 \mathrm{H}_{2} \mathrm{O}, 0.01 \% \mathrm{CoSO}_{4} \cdot 6 \mathrm{H}_{2} \mathrm{O}, 0.009 \% \mathrm{Na}_{2}$ $\mathrm{SeO}_{3}, 0.012 \%$ ethylenediamine dihydroiodide, $0.8 \% \mathrm{CuSO}_{4} .5 \mathrm{H}_{2} \mathrm{O}$, $680,000 \mathrm{IU} / \mathrm{kg}$ of vitamin A, $160,000 \mathrm{IU} / \mathrm{kg}$ of vitamin D, and 2,000 IU/kg of vitamin E.

$42 \%$ of CS (Table 2) but differed in peNDF level: high, medium, and low. The 3 dietary peNDF levels were obtained using CS differing in particle length: $100 \%$ long silage (high), $25 \%$ long silage $+75 \%$ medium silage (medium), and $100 \%$ fine silage (low). The diets were formulated using the Cornell-Penn-Miner System (CPMDairy, Version 2.23; Cornell University, Ithaca, NY; University of Pennsylvania, Kennett Square, PA; and William H. Miner Agricultural Research Institute, Chazy, NY) to supply adequate metabolizable energy and metabolizable protein for a $600-\mathrm{kg}$ cow producing $35 \mathrm{~kg} / \mathrm{d}$ of milk with $3.5 \%$ fat and $3.2 \%$ protein. Each period consisted of $11 \mathrm{~d}$ of adaptation to diets and 10 d of experimental measurements.

Feed offered and orts were measured and recorded daily during the last $10 \mathrm{~d}$ of the period to calculate feed intake. Feed samples including CS and TMR were collected once weekly, and orts were collected daily and composited weekly for particle distribution analysis and DM determination on a weekly basis, and then composited by period. The composited samples were dried in an oven at $55^{\circ} \mathrm{C}$ for $48 \mathrm{~h}$ and then ground through a 1-mm diameter screen (standard model 4, Arthur Thomas Co., Philadelphia, PA) for analysis of $\mathrm{OM}, \mathrm{NDF}, \mathrm{ADF}$, starch, and CP. One kilogram of each
CS (long, medium, and fine) was obtained weekly. Particle size distribution of the silage was determined using the PSPS containing 2 sieves (19 and $8 \mathrm{~mm}$ ) and a pan (Table 3). The DM content was analyzed by oven drying at $55^{\circ} \mathrm{C}$ for $48 \mathrm{~h}$. The samples were then composited by experimental period and retained for determination of chemical composition.

\section{Meal Duration and Eating Behavior}

Eating behavior was monitored for $72 \mathrm{~h}$, during which chewing was also monitored. Feed mangers were attached to load cells (Omega Engineering Inc., Stamford, CT), which were connected to a computer. The load cells monitored feed weight continually and an average weight was obtained every $11 \mathrm{~s}$ and was stored using Collect software (Labtronics, Inc., Guelph, ON, Canada). Feeding activity was separated into meals using a meal criterion of $27 \mathrm{~min}$ as outlined by DeVries et al. (2003). The meal criterion was used as the minimum interval between 2 meals for determining meal frequency and meal duration. A meal was defined as eating activity greater than $30 \mathrm{~s}$ and more than $300 \mathrm{~g}$ of feed being removed from the feeder. Rate of DMI was calculated as the ratio of DM ingested and duration of the meal.

\section{Chewing Behavior}

Cows were fitted with leather halters for $72 \mathrm{~h}$ that were equipped to measure jaw movements during $\mathrm{d} 12$ to 15 of the period. Each halter contained a piezo disk (Edmund Scientific Co., Barrington, NJ), which was inserted within the halter and positioned under the jaw. Chewing action places stress on the disk generating an electrical signal, which is then processed and counted as a single jaw movement. A datalogger (Campbell Scientific, Inc., Logan, UT) was used to receive the output signal from each cow. The number of jaw movements was summed each minute and stored until retrieval. The jaw movements were then designated as eating or ruminating chews. Jaw movements were considered eating chews if they occurred during a meal (i.e., duration of the eating activity was greater than $30 \mathrm{~s}$ and more than $300 \mathrm{~g}$ of feed was removed from the feeder during the meal). Jaw movements were designated as ruminating chews if they did not occur during a meal and rate of chewing exceeded 30 chews $/ \mathrm{min}$. All other jaw movements were considered associated with licking, drinking, and grooming, and not included in the eating or ruminating categories. Total number of chews was calculated as the sum of eating and ruminating chews. Total time spent eating, ruminating, and chewing (eating + ruminating) was based on the duration of 
Table 3. Particle size distribution of corn silage measured using the Penn State Particle Separator.

\begin{tabular}{lccccccc}
\hline & \multicolumn{3}{c}{ Corn silage } & & \multicolumn{2}{c}{ Effects } \\
\cline { 2 - 3 } Item & Long & Medium & Fine & SE & & Linear & Quadratic \\
\hline Chemical, \% DM & & & & & & \\
OM & 93.8 & 93.7 & 93.9 & 0.2 & NS & NS \\
NDF & 46.4 & 46.9 & 46.0 & 0.3 & NS & NS \\
ADF & 27.2 & 27.1 & 26.6 & 0.3 & NS & NS \\
Starch & 28.6 & 28.5 & 28.0 & 0.4 & NS & NS \\
N & 1.39 & 1.41 & 1.39 & 0.02 & NS & NS \\
Particle, \% DM retained on sieve & & & & & & \\
19.0-mm & 20.6 & 17.8 & 16.5 & 0.9 & 0.01 & NS \\
8.0-mm & 63.5 & 54.8 & 50.7 & 1.0 & 0.01 & NS \\
Pan & 15.9 & 27.4 & 32.8 & 1.7 & 0.01 & NS \\
pef & 0.84 & 0.73 & 0.67 & 0.02 & 0.01 & NS \\
\hline
\end{tabular}

${ }^{1}$ pef $=$ Physical effectiveness factor determined as the proportion of particles (DM basis) retained by both sieves of the Penn State Particle Separator.

$\mathrm{NS}=P>0.15$.

chewing activity. In the event of electrical or mechanical damage, corrupted data were deleted and measurements were made at a later time.

\section{Ruminal pH and Fermentation}

Ruminal $\mathrm{pH}$ was monitored for $72 \mathrm{~h}$ concurrently with measurements of chewing and eating behavior during d 12 to 15 of the period. The $\mathrm{pH}$ was measured using an industrial probe (model PHCN-37, Omega Engineering Inc.) that was modified for use in the rumen environment. The probe was anchored approximately $60 \mathrm{~cm}$ from the electrode, minimizing the opportunity for the electrode to relocate itself in the reticulum. Probes were weighted to ensure submersion within the rumen contents; however, the extent of their movement within the rumen was not determined. Thus, it should be recognized that these measurements of rumen $\mathrm{pH}$ might not correspond to manual measurements of $\mathrm{pH}$ taken from precise locations within the rumen. The probes were covered with a mesh guard to prevent them from coming into direct contact with the rumen wall. Continuous measurements from the indwelling probe were sent to a datalogger (Campbell Scientific, Inc.) every $5 \mathrm{~s}$ and were averaged every $5 \mathrm{~min}$. Ruminal $\mathrm{pH}$ data were summarized daily for each cow as mean $\mathrm{pH}$, minimum $\mathrm{pH}$, maximum $\mathrm{pH}$, area under the curve, area between the curve and a horizontal line at $\mathrm{pH} 5.8$ or 5.5 , and time (h) under $\mathrm{pH} 5.8$ or 5.5. The area was calculated by adding the absolute value of negative deviations in $\mathrm{pH}$ from 5.5 or 5.8 for each 15 -min interval. In the event of equipment malfunction all corrupted data were deleted and measurements were repeated at a later time during the period. The ruminal $\mathrm{pH} 5.8$ was chosen as benchmark because a $\mathrm{pH}$ below 5.8 , but above 5.0 , is often used to indicate subclinical ruminal acidosis and the incidence of subclinical acidosis increases when ruminal $\mathrm{pH}$ falls below 5.8 .

Ruminal fluid was collected on d 13 at 1000, 1300, and $1600 \mathrm{~h}$ from multiple sites in the rumen for VFA and $\mathrm{NH}_{3} \mathrm{~N}$ determination. Samples were immediately squeezed through 4 layers of cheesecloth with a mesh size of $250 \mu \mathrm{m}$. Five milliliters of filtrate was preserved by adding $1 \mathrm{~mL}$ of $25 \% \mathrm{HPO}_{3}$ and used to determine VFA, and $5 \mathrm{~mL}$ of filtrate was preserved by adding 1 $\mathrm{mL}$ of $1 \% \mathrm{H}_{2} \mathrm{SO}_{4}$ and used to determine $\mathrm{NH}_{3} \mathrm{~N}$. The samples were subsequently stored frozen at $-20^{\circ} \mathrm{C}$ until analyzed.

\section{Rate of Passage}

Passage rate of digesta from the rumen or the postruminal tract was measured using Cr-mordanted NDF and CoEDTA as forage and liquid markers, respectively. Fiber from long, medium, and fine chopped silage was separately prepared by washing in a washing machine twice with detergent and then boiled for $4 \mathrm{~h}$ in diluted detergent solution until the NDF content of the material exceeded $85 \%$. Methods used to mordant $\mathrm{Cr}$ to plant cell walls and to prepare CoEDTA were those of Udén et al. (1980). Two hundred fifty grams of Crmordanted NDF and $300 \mathrm{~mL}$ of solution containing 15 $\mathrm{g}$ of CoEDTA were introduced in the rumen via the ruminal cannulas. Fecal samples were collected from the rectum at $0,6,9,12,15,18,24,30,36,48,72,96$, and $120 \mathrm{~h}$ after dosing with the markers. A double compartmental model represented by 2 exponential constants and a time delay (Grovum and Williams, 1973) was used:

$$
\begin{aligned}
& \mathrm{Y}=\mathrm{A} \mathrm{e}^{-\mathrm{k} 1(\mathrm{t}-\mathrm{TT})}-\mathrm{Ae}^{-\mathrm{k} 2(\mathrm{t}-\mathrm{TT})}, \mathrm{k} 1<\mathrm{k} 2 \text { for } \mathrm{t} \geq \mathrm{TT} \\
& \mathrm{Y}=0 \text { for } \mathrm{t}<\mathrm{TT} \text {, }
\end{aligned}
$$


where $\mathrm{Y}=$ marker concentration $(\mathrm{mg} / \mathrm{kg}) ; \mathrm{A}=$ scale parameter; $\mathrm{k} 1$ = ruminal rate of passage $(\% / \mathrm{h}) ; \mathrm{k} 2=$ lower digestive tract rate of passage \%/h); $\mathrm{t}=$ sampling time post-dosing (h); and TT = transit time. Total mean retention time in the digestive tract was calculated as the sum of retention in the rumen $(1 / \mathrm{k} 1)$ and in the lower digestive tract $(1 / \mathrm{k} 2)$ plus the transit time (TT).

Data were analyzed by nonlinear regression using the NLIN (iterative Marquardt method) procedure of SAS (SAS Institute, 1996).

\section{Chemical Analyses}

Ingredient (silage, grain, concentrate mix) and diet $\mathrm{DM}$ was determined by oven-drying at $55^{\circ} \mathrm{C}$ for $48 \mathrm{~h}$. Analytical DM content of the dietary and fecal samples was determined by drying at $135^{\circ} \mathrm{C}$ for $3 \mathrm{~h}$ (AOAC, 1990). The OM content was calculated as the difference between DM and ash contents, with ash determined by combustion at $550^{\circ} \mathrm{C}$ overnight. The NDF and ADF contents were determined using the methods described by Van Soest et al. (1991) with amylase and sodium sulfite used in the NDF procedure. Starch was determined by enzymatic hydrolysis of $\alpha$-linked glucose polymers as described by Rode et al. (1999). Contents of $\mathrm{Cr}$ and $\mathrm{Co}$ in the samples were determined using inductively coupled plasma optical emission spectroscopy according to the AOAC method (1990) modified such that no calcium chloride was used during sample digestion. Content of $\mathrm{N}$ in the samples was determined according to the method of Smith and Tabatabai (2004) by flash combustion, chromatographic separation, and thermal conductivity detection (Carlo Erba Instruments, Milan, Italy). Ruminal VFA were separated and quantified by gas chromatography (Varian 3700; Varian Specialties Ltd., Brockville, ON, Canada) using a 15-m (0.53-mm i.d.) fused silica column (DB-FFAP column; J and W Scientific, Folsom, CA). Ammonia content of ruminal samples was determined using the method described by Weatherburn (1967) modified to use a plate reader. Particle size distributions of CS, TMR, and orts were determined using the PSPS (Lammers et al., 1996). Physical effectiveness factors for silage, TMR, and orts were calculated as the sum of the proportions of the materials retained on the 19.0- and $8.0-\mathrm{mm}$ sieves of the PSPS. The peNDF of the diets was determined by multiplying the pef of the TMR by the NDF content (DM basis) of the diet.

\section{Statistical Analyses}

Data were analyzed using the mixed model procedure of SAS (Proc Mixed; SAS Institute, 1996) to account for effects of square, period within square, cow within square, and treatment. The treatment was considered a fixed effect; square, period within square, and cow within square were considered random effects. Estimation method was restrictive maximum likelihood (REML) and the degrees of freedom method was Kenward-Rogers. Data for meal, chewing activity, and ruminal $\mathrm{pH}$ were summarized by day and then analyzed using the same mixed model but with day included as a repeated measure and using compound symmetry. Similarly, data for VFA and ammonia were analyzed by sampling time using repeated measures techniques. Data for particle distribution, pef and peNDF of forages and diets were averaged by period and analyzed by including particle length as a fixed effect and period as a random effect. Linear and quadratic orthogonal contrasts were tested using the CONTRAST statement of SAS. Pearson correlation coefficients were estimated using the CORR procedure of SAS. Effects of the factors were declared significant at $P<0.05$ unless otherwise noted and trends were discussed at $P<0.15$.

\section{RESULTS}

\section{Feed Particle Length and Physically Effective Fiber}

Rechopping CS to produce medium and fine silages did not modify chemical composition of the CS, but linearly reduced the proportion of particles on both sieves of the PSPS (Table 3). Consequently, pef was linearly decreased with rechopping. However, reduction of pef was more pronounced by chopping the original silage once to produce the medium silage (pef was reduced by $14 \%$ ) than by further rechopping to produce the fine silage (pef was reduced by $7 \%$ ).

For the diets offered, the proportion of particles on the first and second sieves, and pef linearly decreased because of decreasing particle length of CS (Table 4). The pef of the TMR (range of 0.28 to 0.35 ) was significantly lower than that of the CS (range of 0.67 to 0.84 ) because nearly $60 \%$ of TMR was concentrates that mostly passed through the $8.0-\mathrm{mm}$ sieve. The peNDF value of the TMR linearly decreased with decreasing particle length of CS and reflected the pef of the TMR.

Particle distributions of orts differed from those of the original TMR. The proportion of particles retained on the top and bottom sieves of the PSPS was lower for orts than for the original TMR, demonstrating preferential consumption of longer feed particles by cows. Averaged over the 3 diets, the pef and peNDF contents of the orts were 39 and $28 \%$ lower, respectively, than for the TMR. Thus, the pef of the diets consumed, after adjustment for the pef and peNDF of the orts, ranged from 0.32 to 0.38 and the peNDF ranged from 10.1 to $12.3 \%$. 
Table 4. Effects of reducing silage particle length on particle distribution, physical effectiveness factor (pef), and physically effective fiber (peNDF) contents of the diets and orts.

\begin{tabular}{|c|c|c|c|c|c|c|}
\hline & \multicolumn{3}{|c|}{ Dietary peNDF } & \multirow[b]{2}{*}{$\mathrm{SE}$} & \multicolumn{2}{|c|}{ Effects } \\
\hline & High & Medium & Low & & Linear & Quadratic \\
\hline \multicolumn{7}{|c|}{ TMR offered } \\
\hline \multicolumn{7}{|c|}{ \% DM retained on sieve } \\
\hline 19.0-mm & 8.6 & 7.9 & 7.0 & 0.2 & 0.01 & NS \\
\hline $8.0-\mathrm{mm}$ & 26.6 & 24.4 & 21.5 & 0.7 & 0.01 & NS \\
\hline Pan & 64.7 & 67.7 & 71.5 & 0.9 & 0.01 & NS \\
\hline pef $^{1}$ & 0.35 & 0.32 & 0.30 & 0.01 & 0.01 & NS \\
\hline peNDF, ${ }^{2} \%$ of DM & 11.5 & 10.3 & 8.9 & 0.5 & 0.01 & NS \\
\hline \multicolumn{7}{|c|}{ TMR consumed (adjusted for particle size of orts) } \\
\hline \multicolumn{7}{|c|}{$\% \mathrm{DM}$ retained on sieve } \\
\hline $19.0-\mathrm{mm}$ & 9.2 & 9.3 & 9.4 & 0.6 & NS & NS \\
\hline $8.0-\mathrm{mm}$ & 28.8 & 25.8 & 22.9 & 0.6 & 0.01 & NS \\
\hline Pan & 62.1 & 64.9 & 67.7 & 0.8 & 0.01 & NS \\
\hline pef & 0.38 & 0.35 & 0.32 & 0.01 & 0.01 & NS \\
\hline peNDF, \% of DM & 12.3 & 11.1 & 10.1 & 0.5 & 0.01 & NS \\
\hline \multicolumn{7}{|c|}{ Orts } \\
\hline \multicolumn{7}{|c|}{$\%$ DM retained on sieve } \\
\hline $19.0-\mathrm{mm}$ & 6.3 & 1.7 & 0.2 & 1.0 & 0.01 & NS \\
\hline $8.0-\mathrm{mm}$ & 17.1 & 18.1 & 15.6 & 2.5 & NS & NS \\
\hline Pan & 76.7 & 80.2 & 84.2 & 3.1 & 0.11 & NS \\
\hline pef & 0.23 & 0.20 & 0.16 & 0.03 & 0.11 & NS \\
\hline peNDF, \% of DM & 9.4 & 7.3 & 5.7 & 1.4 & 0.09 & NS \\
\hline
\end{tabular}

${ }^{1}$ pef $=$ Determined as the proportion of particles retained by both sieves of the Penn State Particle Separator.

${ }^{2}$ peNDF $=$ Measured as the NDF content of the TMR multiplied by the pef.

$\mathrm{NS}=P>0.15$.

\section{Intake, Chewing Activity, and Meal Patterns}

Intakes of DM and NDF were not affected by dietary peNDF (Table 5). Intake of peNDF followed the same trend as pef contents of the diets and linearly decreased with reducing dietary peNDF.

Decreasing peNDF content of the diet linearly reduced number of eating chews (chews/d) and tended ( $P$ $<0.15)$ to reduce number of ruminating chews, and consequently reduced number of total chews (Table 6). Number of eating and ruminating chews per unit of NDF was not affected by dietary peNDF content. Pattern of diurnal eating activity of cows was similar among the treatments (Figure 1a). The highest eating activity was observed after the $1500 \mathrm{~h}$ feeding followed by activity at the 2 other feeding times ( 0800 and 1800 h). Eating activity was also high at $0600 \mathrm{~h}$, which was the feeding time of these cows before the experiment started. Eating time $(\mathrm{min} / \mathrm{d})$ was linearly $(P<0.08)$ affected by dietary peNDF with highest eating time for cows fed the medium peNDF and lowest eating time for cows fed the low peNDF diet. As expected, duration of ruminating $(\mathrm{min} / \mathrm{d}, P<0.10)$ and duration of total chewing $(\mathrm{min} / \mathrm{d})$ were linearly increased with increasing dietary peNDF. In contrast, when expressed as min-

Table 5. Effects of reducing dietary physically effective fiber (peNDF) on feed intake of lactating dairy cows.

\begin{tabular}{|c|c|c|c|c|c|c|}
\hline \multirow[b]{2}{*}{ Item } & \multicolumn{3}{|c|}{ Dietary peNDF } & \multirow[b]{2}{*}{$\mathrm{SE}$} & \multicolumn{2}{|c|}{ Effects } \\
\hline & High & Medium & Low & & Linear & Quadratic \\
\hline \multicolumn{7}{|l|}{ DMI } \\
\hline $\mathrm{kg} / \mathrm{d}$ & 21.1 & 21.0 & 20.0 & 4.0 & NS & NS \\
\hline$\%$ of BW & 3.31 & 3.28 & 3.04 & 0.32 & NS & NS \\
\hline NDF intake, kg/d & 6.6 & 6.5 & 5.9 & 1.3 & NS & NS \\
\hline $\mathrm{peNDF}^{1}$ intake, $\mathrm{kg} / \mathrm{d}$ & 2.5 & 2.3 & 1.9 & 0.2 & 0.09 & NS \\
\hline \multicolumn{7}{|l|}{ Intake of particles, $\mathrm{kg} / \mathrm{d}$} \\
\hline$>19.0 \mathrm{~mm}$ & 1.94 & 1.94 & 1.75 & 0.18 & NS & NS \\
\hline 19.0 to $8.0 \mathrm{~mm}$ & 6.10 & 5.45 & 4.56 & 0.58 & 0.09 & NS \\
\hline $\mathrm{BW}, \mathrm{kg}$ & 638 & 637 & 639 & 68 & NS & NS \\
\hline
\end{tabular}

${ }^{1}$ peNDF $=$ Measured as the NDF content of the TMR multiplied by the pef. $\mathrm{NS}=P>0.15$. 
Table 6. Effects of reducing dietary physically effective fiber (peNDF) on chewing activity of lactating dairy cows.

\begin{tabular}{|c|c|c|c|c|c|c|}
\hline \multirow[b]{2}{*}{ Item } & \multicolumn{3}{|c|}{ Dietary peNDF } & \multirow[b]{2}{*}{$\mathrm{SE}$} & \multicolumn{2}{|c|}{ Effects } \\
\hline & High & Medium & Low & & Linear & Quadratic \\
\hline \multicolumn{7}{|l|}{ Eating } \\
\hline Chews/d & 17,994 & 17,474 & 14,047 & 3113 & 0.02 & NS \\
\hline Chews/kg of DM & 881 & 840 & 736 & 115 & 0.10 & NS \\
\hline Chews/kg of NDF & 2820 & 2773 & 2492 & 383 & NS & NS \\
\hline $\mathrm{Min} / \mathrm{d}$ & 289.7 & 296.3 & 260.4 & 14.3 & 0.08 & 0.12 \\
\hline Min/kg of DM & 14.3 & 14.7 & 14.1 & 2.8 & NS & NS \\
\hline $\mathrm{Min} / \mathrm{kg}$ of NDF & 46.4 & 48.2 & 47.9 & 9.9 & NS & NS \\
\hline $\mathrm{Min} / \mathrm{kg}$ of $\mathrm{peNDF}^{1}$ & 121.4 & 136.2 & 142.3 & 28.1 & 0.07 & NS \\
\hline \multicolumn{7}{|l|}{ Ruminating } \\
\hline Chews/d & 33,006 & 31,355 & 30,209 & 2754 & 0.15 & NS \\
\hline Chews/kg of DM & 1601 & 1519 & 1560 & 127 & NS & NS \\
\hline Chews/kg of NDF & 5153 & 4976 & 5315 & 459 & NS & NS \\
\hline $\operatorname{Min} / \mathrm{d}$ & 493.6 & 471.8 & 441.4 & 44.5 & 0.10 & NS \\
\hline Min/kg of DM & 24.4 & 23.1 & 23.4 & 2.5 & NS & NS \\
\hline $\mathrm{Min} / \mathrm{kg}$ of $\mathrm{NDF}$ & 78.3 & 75.8 & 79.9 & 9.0 & NS & NS \\
\hline $\mathrm{Min} / \mathrm{kg}$ of peNDF & 204.5 & 213.9 & 236.1 & 24.6 & 0.12 & NS \\
\hline \multicolumn{7}{|l|}{ Total chewing } \\
\hline Chews/d & 51,000 & 48,829 & 44,256 & 7801 & 0.03 & NS \\
\hline Chews/kg of DM & 2482 & 2359 & 2296 & 208 & NS & NS \\
\hline Chews/kg of NDF & 7974 & 7749 & 7807 & 737 & NS & NS \\
\hline $\operatorname{Min} / \mathrm{d}$ & 783.3 & 768.1 & 701.8 & 41.3 & 0.02 & NS \\
\hline Min/kg of DM & 38.7 & 37.8 & 37.5 & 5.3 & NS & NS \\
\hline $\mathrm{Min} / \mathrm{kg}$ of $\mathrm{NDF}$ & 124.8 & 124.0 & 127.8 & 18.8 & NS & NS \\
\hline $\mathrm{Min} / \mathrm{kg}$ of peNDF & 325.9 & 350.2 & 378.3 & 52.5 & 0.10 & NS \\
\hline \multicolumn{7}{|l|}{ Meal patterns } \\
\hline Meals/d & 9.1 & 10.1 & 9.0 & 0.7 & NS & 0.07 \\
\hline Meal length, min/meal & 32.6 & 30.8 & 28.9 & 2.6 & NS & NS \\
\hline $\begin{array}{l}\text { Meal s1ze, kg } \\
\text { DM }\end{array}$ & 2.35 & 2.21 & 2.27 & 0.53 & NS & NS \\
\hline $\mathrm{NDF}$ & 0.73 & 0.68 & 0.67 & 0.17 & 0.13 & NS \\
\hline peNDF & 0.28 & 0.24 & 0.22 & 0.06 & 0.01 & NS \\
\hline Intake rate, $\mathrm{g}$ of $\mathrm{DM} / \mathrm{min}$ & 72.5 & 71.1 & 79.7 & 14.3 & NS & NS \\
\hline
\end{tabular}

${ }^{1}$ peNDF $=$ Measured as the NDF content of the TMR multiplied by the pef (Table 4 ).

$\mathrm{NS}=P>0.15$.

ute per unit of peNDF, total chewing time $(P<0.10)$, as well as eating $(P<0.07)$ and ruminating time $(P<$ 0.12 ) tended to decrease with increasing dietary peNDF.

Number of meals per day varied from 9 to 10 and tended $(P<0.07)$ to be quadratically affected with dietary peNDF (Table 6). However, duration of meals was not significantly affected by dietary peNDF. Reducing dietary peNDF did not affect amount of DM per meal but linearly reduced amounts of $\mathrm{NDF}(P<0.13)$ and peNDF consumed per meal. Intake rate ( $g$ of DM/min) was similar among the treatments. Diurnal variation in amount of feed consumed by cows generally followed the pattern of eating time (Figure 1). An exception was observed for cows during the period from 0100 to 0300 $\mathrm{h}$, in which feed intake was higher for cows fed the low peNDF diet.

\section{Rate of Passage}

Rumen liquid dilution rate and rumen solid passage rate averaged 10.9 and $3.1 \%$, respectively, and were not affected by dietary peNDF (Table 7). No effects of the treatments were observed for mean retention time of liquid or solids in the total tract, although unexpectedly, postruminal transit time of solids numerically increased with decreasing dietary peNDF.

\section{Ruminal $\mathrm{pH}$ and Fermentation}

Diurnal pattern of ruminal $\mathrm{pH}$ for all treatments appeared to be highest just before $0600 \mathrm{~h}$ and before the $1500 \mathrm{~h}$ feeding (Figure 1). Ruminal $\mathrm{pH}$ was also lower $(P<0.15)$ after the 0800 and $1500 \mathrm{~h}$ feedings for the low peNDF diet compared with the medium peNDF diet. Mean rumen $\mathrm{pH}$, area under $\mathrm{pH} 5.8$ or 5.5 , and duration of $\mathrm{pH}<5.8$ or $\mathrm{pH}<5.5$ were not affected by dietary peNDF (Table 8). The highest $\mathrm{pH}$ was 6.29 and lowest 5.01, but no differences were observed across treatments.

Total concentration of VFA linearly increased from 122 to $132 \mathrm{~m} M$ with reducing dietary peNDF (Table 8). The same effect was observed for molar proportion of propionate, which increased from 28 to $32 \mathrm{~mol} / 100 \mathrm{~mol}$, 

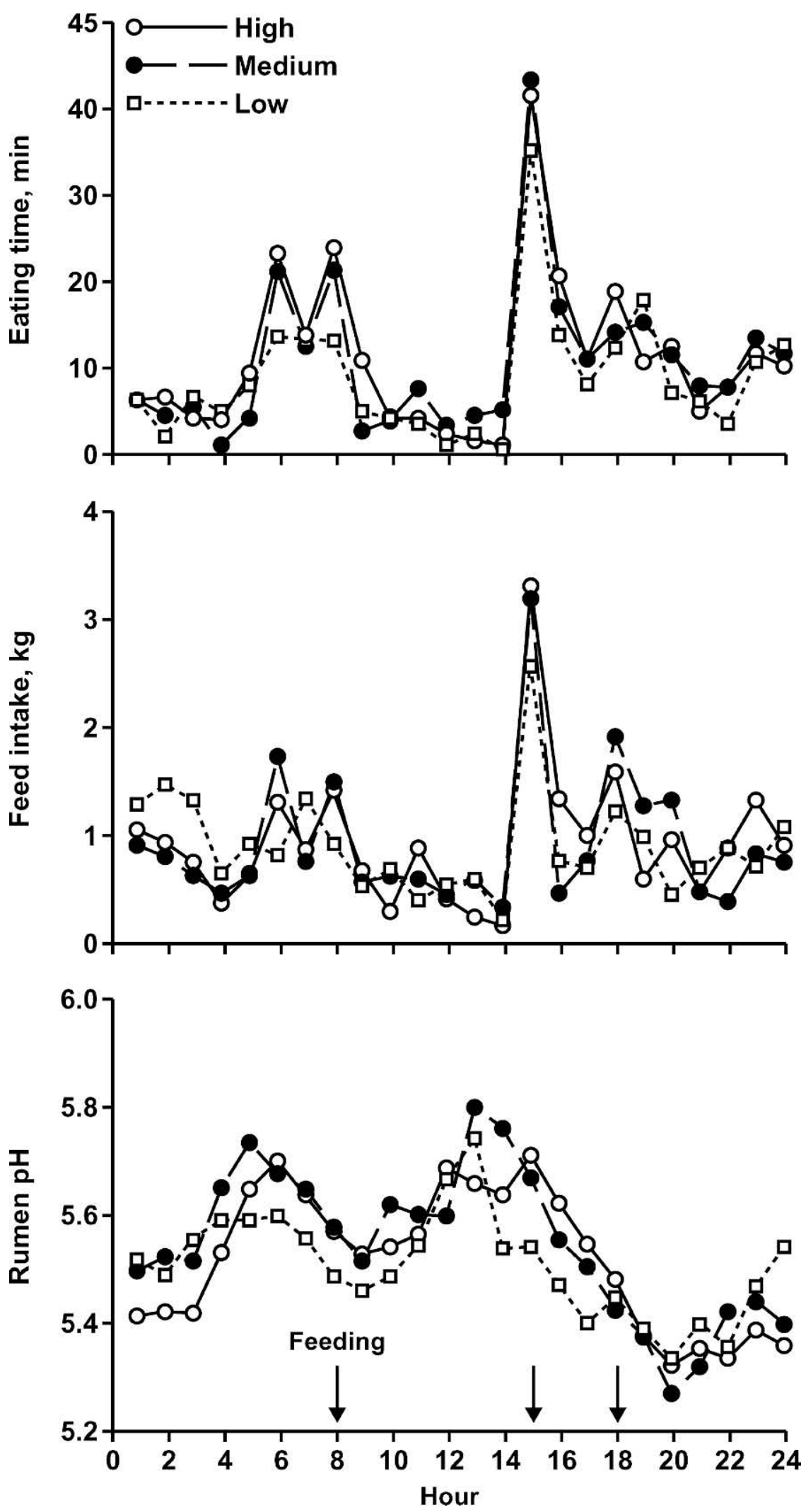

Figure 1. Effects of intake of physically effective NDF (peNDF; high, $\bigcirc$; medium, $\bullet$; and low, $\square$ ) on diurnal variation of eating time, amount of feed consumed in each hour, and rumen $\mathrm{pH}$. Arrows indicate feeding times. 
Table 7. Effects of reducing dietary physically effective fiber (peNDF) on passage rate and retention time ${ }^{1}$ of particles and liquid in the gastrointestinal tract of dairy cows.

\begin{tabular}{|c|c|c|c|c|c|c|}
\hline \multirow[b]{2}{*}{ Item } & \multicolumn{3}{|c|}{ Dietary peNDF } & \multirow[b]{2}{*}{$\mathrm{SE}$} & \multicolumn{2}{|c|}{ Effects } \\
\hline & High & Medium & Low & & Linear & Quadratic \\
\hline \multicolumn{7}{|l|}{ Liquid } \\
\hline $\mathrm{LORR}^{2} \% / \mathrm{h}$ & 10.3 & 10.9 & 11.6 & 1.4 & NS & NS \\
\hline $\mathrm{MRT}^{3}$ in the total tract, $\mathrm{h}$ & 23.0 & 24.0 & 24.9 & 1.5 & NS & NS \\
\hline \multicolumn{7}{|l|}{ Forage particles } \\
\hline PORR, ${ }^{4} \% / \mathrm{h}$ & 3.1 & 2.7 & 3.6 & 0.8 & NS & NS \\
\hline Postruminal transit time, $\mathrm{h}$ & 9.2 & 10.3 & 11.2 & 1.0 & 0.15 & NS \\
\hline $\mathrm{MRT}^{3}$ in the total tract, $\mathrm{h}$ & 52.0 & 57.7 & 56.1 & 7.1 & NS & NS \\
\hline
\end{tabular}

${ }^{1}$ Markers: liquid, Co-EDTA; solids, Cr-mordanted NDF. The 2-compartmental fecal model of Grovum and Williams (1973) was used for calculation.

${ }^{2} \mathrm{LORR}=$ Liquid outflow rate from the reticulorumen.

${ }^{3} \mathrm{MRT}=$ Mean retention time.

${ }^{4} \mathrm{PORR}=$ Particulate outflow rate from the reticulorumen.

$\mathrm{NS}=P>0.15$.

but the opposite was observed for molar proportion of butyrate, which decreased from 12 to $10 \mathrm{~mol} / 100 \mathrm{~mol}$, and for acetate to propionate ratio, which reduced from 2.04 to 1.69 with reducing dietary peNDF. There was no effect of dietary peNDF on ammonia concentration in the rumen.

\section{DISCUSSION}

Particle size of CS used in commercial dairy operations is extremely variable. When measured using the PSPS, Heinrichs et al. (1999) reported that, on average,
CS samples contained $8.1 \pm 6.4 \%$ of the DM greater than $19.0 \mathrm{~mm}$, but varied from 1 to $81 \%$. The TCL used to harvest the CS is not the only factor that determines particle length; it is also influenced by type of harvesting equipment, as well as plant variety and maturity (Johnson et al., 2002). For the long silage used in the present study, proportion of particles on the 19.0- or 8.0-mm sieves was greater than the average for more than 5000 samples in the study reported by Heinrichs et al. (1999). However, for the fine CS, the proportion of particles on the $8.0-\mathrm{mm}$ sieve was similar to the average of the survey. Comparing our results with those

Table 8. Effects of reducing dietary physically effective fiber (peNDF) on rumen $\mathrm{pH}$ and fermentation characteristics of dairy cows in early lactation.

\begin{tabular}{|c|c|c|c|c|c|c|}
\hline \multirow[b]{2}{*}{ Item } & \multicolumn{3}{|c|}{ Dietary peNDF } & \multirow[b]{2}{*}{$\mathrm{SE}$} & \multicolumn{2}{|c|}{ Effects } \\
\hline & High & Medium & Low & & Linear & Quadratic \\
\hline \multicolumn{7}{|l|}{$\mathrm{pH}$} \\
\hline Mean & 5.49 & 5.51 & 5.49 & 0.13 & NS & NS \\
\hline Area under curve, $\mathrm{pH} \times \mathrm{h} / \mathrm{d}$ & 125.6 & 126.0 & 125.3 & 2.9 & NS & NS \\
\hline Area under $\mathrm{pH} 5.8, \mathrm{pH} \times \mathrm{h} / \mathrm{d}$ & 8.9 & 8.9 & 8.3 & 1.9 & NS & NS \\
\hline Area under $\mathrm{pH} 5.5, \mathrm{pH} \times \mathrm{h} / \mathrm{d}$ & 4.2 & 4.1 & 3.7 & 0.9 & NS & NS \\
\hline $\mathrm{pH}<5.8, \mathrm{~h} / \mathrm{d}$ & 17.6 & 17.1 & 17.6 & 2.9 & NS & NS \\
\hline $\mathrm{pH}<5.5, \mathrm{~h} / \mathrm{d}$ & 13.8 & 13.9 & 13.0 & 3.1 & NS & NS \\
\hline Highest & 6.29 & 6.28 & 6.28 & 0.12 & NS & NS \\
\hline Lowest & 5.01 & 5.02 & 5.05 & 0.07 & NS & NS \\
\hline \multicolumn{7}{|l|}{ VFA } \\
\hline Total, $\mathrm{m} M$ & 122.6 & 122.1 & 132.7 & 5.1 & 0.04 & 0.13 \\
\hline \multicolumn{7}{|l|}{$\mathrm{Mol} / 100 \mathrm{~mol}$} \\
\hline Acetate (A) & 55.8 & 56.0 & 53.9 & 1.2 & NS & NS \\
\hline Propionate $(\mathrm{P})$ & 28.3 & 28.8 & 32.1 & 1.5 & 0.04 & NS \\
\hline Butyrate & 11.8 & 11.1 & 10.0 & 1.1 & 0.05 & NS \\
\hline BCFA $^{1}$ & 1.9 & 1.9 & 1.8 & 0.1 & 0.15 & NS \\
\hline Valerate & 1.9 & 1.9 & 1.9 & 0.3 & NS & NS \\
\hline Caproic & 0.3 & 0.3 & 0.2 & 0.1 & NS & NS \\
\hline $\mathrm{A}: \mathrm{P}$ & 2.04 & 1.99 & 1.69 & 0.15 & 0.07 & NS \\
\hline $\mathrm{NH}_{3} \mathrm{~N}, \mathrm{~m} M$ & 5.09 & 5.58 & 4.93 & 0.84 & NS & NS \\
\hline
\end{tabular}

${ }^{1} \mathrm{BCFA}=$ Branched-chain fatty acids (isobutyrate + isovalerate).

$\mathrm{NS}=P>0.15$. 
of Kononoff et al. (2003), the pef of ensiled (long) and rechopped (medium) silages were similar between the 2 studies, but the proportion of particles retained on the $19.0-\mathrm{mm}$ sieve was lower (20.6 vs. $25.9 \%$ ), and that retained on the $8.0-\mathrm{mm}$ sieve was higher (17.8 vs. $6.8 \%$ ) in our study. This difference was probably because of differences in TCL (19.0 vs. $22.3 \mathrm{~mm}$ ) used to prepare the silage and the different sieve sizes used (11.0 vs. $4.8 \mathrm{~mm}$ ) for rechopping the CS.

When measured using the PSPS with 2 sieves (19 and $8 \mathrm{~mm}$ ), the pef content of barley grain-based diets is mainly dependent on the proportion of forage in the diet and its particle length, because processed barleybased concentrates mostly pass through the 8 -mm sieve. Nevertheless, changes in peNDF content of this barley-based diet by altering forage particle length (FPL) were not as great as expected. For instance, an increase of one percentage unit in pef of CS increased peNDF content of the diets by only 0.13 units (Table 4). The peNDF values (range of 8.9 to $11.5 \%$ ) of the diets offered in the present study were lower than those (range of 20 to 22\%) reported by Kononoff et al. (2003) because a higher proportion of CS (57.4\%) was used in that study.

Sorting in favor of long feed particles was observed in the present study. Furthermore, the finer the diet, the more pronounced the effect. The present findings are in contrast to the reports by Calberry et al. (2003) and Leonardi and Armentano (2003), who observed that cows actually selected against coarse feed particles in favor of fine feed particles when offered alfalfa hay or alfalfa silage-based diets. The discrepancy among these studies may be attributed to the coarser particles used in those studies than in the present study. The peNDF contents of diets ranged from 20.1 to $23.3 \%$ in the study of Calberry et al. (2003). In fact, Plaizier (2004) did not find a greater proportion of particles on the 19- and 8mm PSPS screens compared with the TMR when peNDF contents of the diets ranged from 9.2 to $12.5 \%$. These findings suggests that dairy cows may intentionally select long feed particles to meet their need for physically effective fiber, especially when ruminal $\mathrm{pH}$ is low (Table 8).

The lack of effect of dietary peNDF on intake of DM and NDF is consistent with the results for passage rate from the rumen and mean retention time in the total tract for liquid and solids (Table 7). The present results are in agreement with some studies (Bal et al., 2000; Beauchemin et al., 2003) but in contrast to other studies in which positive effects on DMI and NDF intake from reduced particle size have been reported (Schwab et al., 2002; Kononoff et al., 2003). Feed intake is influenced by digestion rate and passage rate of feeds from the rumen. Lack of effect of dietary peNDF on passage rate of feeds out of the rumen was likely due to increased chewing activity (i.e., number of chews and duration of chewing) with increasing dietary peNDF. Hence, particle size reduction was not a rate-limiting step for particulate passage. Furthermore, effect of dietary peNDF on DMI may depend upon forage level or type of concentrate in the diets of dairy cows. Belyea et al. (1989) reported that decreased FPL increased intake of cows fed only alfalfa hay, but FPL had no effect on intake of cows fed a diet containing alfalfa hay (60\% of diet, DM basis) plus concentrate because ruminal fill was not a limiting factor for DMI. There was no effect of dietary peNDF on DMI for diets containing about $40 \%$ of forage (Beauchemin et al., 2003; present study), whereas an effect on DMI was observed for diets containing about $60 \%$ forage (Schwab et al., 2002; Kononoff et al., 2003).

Although effect of CS particle length on chewing behavior has been investigated in a number of studies, there are no studies to our knowledge that investigated effect of dietary peNDF measured using the PSPS on chewing activity for diets based on CS and barley grain. Increased $(P<0.10)$ number of chews per unit of DM during the eating period with increasing dietary peNDF was in agreement with the observation of Kononoff and Heinrichs (2003a) for cows fed an alfalfa silage-based diet. In contrast, the effect was not observed for cows fed CS-based diets (Kononoff and Heinrichs, 2003b). As the number of chews per unit of DM during ruminating was not affected in the present study, cows efficiently reduced long particles by increasing chewing rate (i.e., chews/min) during eating. The chewing rate was linearly increased from 54.4 to 58.2 , and then to 61.9 for high, medium, and low peNDF diet, respectively. The results may partially explain the similar passage rates of solids out of the rumen across treatments.

In the present study, increased chewing time due to increased eating and ruminating time with increasing dietary peNDF was consistent with the reports of Krause et al. (2002) and Yang et al. (2001). However, lack of effect of dietary peNDF on chewing time per unit of DM and NDF was in contrast to other reports (Beauchemin et al., 2003; Kononoff et al., 2003), and may be attributable to the linearly increased number of chews with increasing dietary peNDF. These results suggest that increased dietary peNDF may affect chewing activity either through prolonging chewing time or increasing chewing rate. Dietary peNDF content was moderately correlated with number of chews during eating $(\mathrm{r}=0.41, P<0.09)$ and with total chewing time $(\mathrm{r}=0.39, P<0.11)$ (Table 9$)$. In addition, it was reported that the particles $>19.0 \mathrm{~mm}$ may be a primary factor affecting chewing activity in dairy cattle fed diets containing alfalfa silage (Kononoff and Heinrichs, 2003a) or CS (Kononoff et al., 2003). However, in the present 
Table 9. Pearson correlation coefficients ${ }^{1}$ between dietary particle size distribution or peNDF ${ }^{2}$ proportion (\% of $\mathrm{DM}$ ) and eating patterns, chewing behaviour, and rumen $\mathrm{pH}$.

\begin{tabular}{|c|c|c|c|c|c|}
\hline \multirow[b]{2}{*}{ Variables } & \multicolumn{5}{|c|}{ Dietary particle length (\% of DM) } \\
\hline & $>19 \mathrm{~mm}$ & $>8 \mathrm{~mm}$ & $<8 \mathrm{~mm}$ & pef & peNDF \\
\hline Meals/d & -0.07 & -0.16 & 0.18 & -0.18 & -0.03 \\
\hline Meal length, min & -0.16 & 0.48 & -0.36 & 0.37 & 0.14 \\
\hline Intake rate, $\mathrm{g}$ of $\mathrm{DM} / \mathrm{min}$ & -0.38 & -0.18 & 0.33 & -0.33 & -0.24 \\
\hline Eating chews/d & 0.05 & 0.55 & -0.45 & 0.45 & 0.41 \\
\hline Eating time, $\mathrm{min} / \mathrm{d}$ & 0.07 & 0.47 & -0.26 & 0.26 & 0.28 \\
\hline Ruminating chews/d & 0.05 & 0.28 & -0.15 & 0.15 & 0.10 \\
\hline Ruminating time, min/d & 0.01 & 0.39 & -0.34 & 0.34 & 0.29 \\
\hline Total chewing time, $\mathrm{min} / \mathrm{d}$ & 0.10 & 0.64 & -0.48 & 0.48 & 0.39 \\
\hline Rumen $\mathrm{pH}$ mean & 0.01 & -0.19 & 0.17 & -0.17 & -0.08 \\
\hline Rumen $\mathrm{pH}<5.8, \mathrm{~h} / \mathrm{d}$ & 0.15 & 0.17 & -0.21 & 0.21 & 0.19 \\
\hline Rumen $\mathrm{pH}<5.5, \mathrm{~h} / \mathrm{d}$ & 0.04 & 0.22 & -0.22 & 0.22 & 0.21 \\
\hline Area under $\mathrm{pH} 5.8, \mathrm{pH} \times \mathrm{h} / \mathrm{d}$ & -0.03 & 0.28 & -0.24 & 0.24 & 0.16 \\
\hline Area under $\mathrm{pH} 5.5, \mathrm{pH} \times \mathrm{h} / \mathrm{d}$ & -0.14 & 0.34 & -0.24 & 0.24 & 0.10 \\
\hline Rumen VFA, $\mathrm{m} M$ & 0.14 & -0.43 & 0.32 & -0.32 & -0.19 \\
\hline
\end{tabular}

${ }^{1}$ Correlation coefficients were significant at $P<0.01$ ( $>0.59$ or $\left.<-0.59\right), P<0.05(>0.47$ or $<-0.47)$, and $P$ $<0.15(>0.36$ or $<-0.36)$.

${ }^{2}$ Particle size distribution was determined using the Penn State Particle Separator (PSPS), physical effectiveness factor (pef) determined as the proportion of particles (DM basis) retained by both sieves of the PSPS, and physically effective NDF (peNDF) estimated as the NDF content of the TMR multiplied by pef. Particle size distributions were adjusted for particle size of orts.

study there was no correlation of proportion of particles $>19.0 \mathrm{~mm}$ with chewing activity because the proportion of particles $>19 \mathrm{~mm}$ was similar after adjustment of particle size of orts, but proportion of particles $>8.0 \mathrm{~mm}$ was moderately correlated $(\mathrm{r}=0.64, P<0.01)$ to chewing time. The correlation between particles $>8.0 \mathrm{~mm}$ and chewing time is in agreement with previous observations that the fraction retained on the second (i.e., 8$\mathrm{mm}$ ) rather than the top (i.e., 19.0-mm) sieve of the PSPS was correlated $(r=0.56)$ to chewing time (Yang and Beauchemin, 2002). The discrepancy in correlation of particle fractions of the PSPS with chewing activity between the studies of Kononoff et al. (2003) and ours is likely due to the differences in particle distribution. In fact, in the studies of Kononoff and Heinrichs (2003a) and Kononoff et al. (2003), the proportion of particles $>19.0 \mathrm{~mm}$ was increased, but the proportion of the particles $>8.0 \mathrm{~mm}$ was decreased with increasing FPL. The present results indicate that increasing peNDF content is an effective means of stimulating chewing activity, whereas the effect of individual particle fractions of the PSPS on chewing activity may depend on the contribution of each particle fraction to the pef.

For barley-based diets, 21 to $23 \%$ NDF from forage is recommended, depending upon the starch content of the diet (Beauchemin and Yang, 2003). It is recommended that the starch content of the diet should not exceed $33 \%$ ( $38 \%$ NFC) and dietary NDF content should be greater than $32 \%$. In the present study, the NDF from forage $(23.2 \%)$, starch $(34.8 \%)$, and NDF (32.6\%) contents were within the range of these recommenda- tions. In terms of the peNDF requirement, Mertens (1997) recommended $19.7 \%$ peNDF to maintain a milk fat of $3.4 \%$, or $22.3 \%$ peNDF to maintain a rumen $\mathrm{pH}$ of 6.0. In that case, the peNDF was estimated by multiplying the proportion of feed greater than $1.18 \mathrm{~mm}$ in length by total ration NDF. Beauchemin et al. (2003) reported that for cows fed alfalfa silage-based diets containing 19\% NDF from forage, peNDF content (range of 7.2 to $15 \%$ ) below $10 \%$ reduced chewing time and negatively affected rumen $\mathrm{pH}$ status. Kononoff and Heinrichs (2003b) reported that chewing activity per unit of DM was not affected by peNDF ranging from 15.6 to $18.4 \%$ for CS-based diets. However, in another study using an alfalfa silage-based diet, Kononoff and Heinrichs (2003a) observed that increased dietary peNDF linearly increased chewing time when dietary peNDF content was lower (10.4 to $15.2 \%$ ). In the present study, although chewing time per unit of DM was not affected, there was a $10 \%$ reduction of chews and chewing time when peNDF content was reduced from 11.1 to $10.1 \%$, but only a 2 to $4 \%$ reduction when peNDF content was reduced from 12.3 to $11.1 \%$. The present results suggest that a level of dietary peNDF above $10 \%$ is required to avoid a reduction of chewing activity.

It is commonly believed that increasing particle length promotes chewing activity and thus increases buffering capacity within the rumen due to increased saliva secretion. Hence, chewing time has been measured as an indirect indication of the potential of the diet to maintain high rumen $\mathrm{pH}$. Unfortunately, this concept is not consistently supported by published re- 
sults. No effect of FPL on rumen $\mathrm{pH}$ was reported (Schwab et al., 2002; Kononoff and Heinrichs, 2003a, b) for CS-based diets although chewing time was affected by FPL. However, those studies only measured mean ruminal $\mathrm{pH}$, which does not reflect the extent of variation in $\mathrm{pH}$ among cows or the extent of diurnal fluctuations in rumen $\mathrm{pH}$ for individual cows. Several studies using continuous indwelling electrodes demonstrated that although mean ruminal $\mathrm{pH}$ was similar, duration of $\mathrm{pH}$ below 5.8 was reduced as particle length of alfalfa silage was increased (Yang et al., 2001; Krause et al., 2002). Beauchemin et al. (2003) further reported that decreased alfalfa FPL reduced mean ruminal $\mathrm{pH}$ by only $4 \%$, but area of the curve under $\mathrm{pH} 5.8$ and duration of $\mathrm{pH}<5.8$ were almost tripled or doubled, respectively. The incidence of subclinical acidosis increases when ruminal $\mathrm{pH}$ falls below 5.8. Beauchemin et al. (2003) observed that diets with higher peNDF concentrations resulted in higher ruminal $\mathrm{pH}$ values and longer rumination time. In the present study, increased chewing activity due to increased dietary peNDF did not significantly change ruminal mean $\mathrm{pH}$ or the diurnal $\mathrm{pH}$ variation. The correlation of particle fractions or peNDF concentration with ruminal $\mathrm{pH}$ was not significant (Table 9). However, it is worthwhile noting that ruminal $\mathrm{pH}$ was numerically higher $(P<0.15)$ for the period from 1400 to $1700 \mathrm{~h}$ for cows fed the high peNDF diet than for cows fed the low peNDF diet (Figure 1). The higher $(P<0.15) \mathrm{pH}$ was likely associated with longer $(P<0.15)$ eating time (Figure 1$)$. The increase in saliva output during eating could enable the cow to buffer the large quantity of fermentation acids produced soon after the feed is consumed. This is particularly beneficial for barley grain-based diets because barley grain is rapidly degradable in the rumen following ingestion.

Rumen $\mathrm{pH}$ is directly affected by the factors that lead to the production of fermentation acids. Therefore, the inconsistent effects of FPL on rumen $\mathrm{pH}$ reported in the literature may be related to other dietary factors including DMI, fermentability of the diet, and feeding management. A poor relationship $\left(\mathrm{r}^{2}=0.13\right)$ between rumen $\mathrm{pH}$ and intake of fiber whether measured as NDF, NDF from forage, or effective NDF was reported in numerous publications in which dairy cows were fed a variety of diets (Beauchemin, 2000). In a study (Yang et al., 2001) to investigate the effects of grain processing, fiber content, and FPL on rumen $\mathrm{pH}$ and digestion, we observed that rumen $\mathrm{pH}$ was significantly affected by the grain processing but not by FPL. It is suggested that additional dietary factors that could affect rumen $\mathrm{pH}$ must be considered when determining the requirement of dietary peNDF by dairy cows. In fact, the concept of peNDF does not account for differ- ences in fermentability of feeds, and does not predict differences in chewing and rumen $\mathrm{pH}$ due to grain fermentability.

\section{CONCLUSIONS}

Increasing the particle length of processed CS increased the intake of peNDF. Increasing dietary peNDF increased chewing activity including the number of chews, and eating and ruminating time of dairy cows. However, increased chewing activity did not improve ruminal pH status, or decrease the incidence of subclinical acidosis. Although increasing dietary peNDF increased rumination, the incremental buffering capacity resulting from increased salivation did not reduce the incidence of ruminal acidosis in dairy cows fed low fiber diets. Thus, in addition to peNDF, fermentation of feed is critical in the regulation of rumen $\mathrm{pH}$.

The Penn State Particle Separator is a useful device that can be used on the farm to measure particle size of forages and TMR. The values obtained using this device can be used to determine the physical effectiveness of fiber, which is a good indication of the rumination potential of the feed.

\section{ACKNOWLEDGMENTS}

This experiment was financially supported by the Dairy Farmers of Canada (Ottawa, ON) and Agriculture and Agri-Food Canada's Matching Investment Initiative. The authors thank K. Andrews, B. Farr, D. Vedres, and R. Wuerfel for their assistance in performing sampling, rumen $\mathrm{pH}$ and chewing measurements, and laboratory analyses, and the staff of the Lethbridge Research Centre dairy unit for care of the cows and milk sample collection.

\section{REFERENCES}

Association of Official Analytical Chemists. 1990. Official Methods of Analysis. Vol. I. 15th ed. AOAC, Arlington, VA.

Bal, M. A., R. D. Shaver, A. J. Jirovec, K. J. Shinners, and J. G. Coors. 2000. Crop processing and chop length of corn silage: Effects on intake, digestion, and milk production by dairy cows. J. Dairy Sci. 83:1264-1273.

Beauchemin, K. A. 2000. Managing rumen fermentation in barley based diets: Balance between high production and acidosis. Adv. Dairy Technol. 12:109-125.

Beauchemin, K. A., and W. Z. Yang. 2003. Forage: How much do dairy cows need in a time scarcity? Adv. Dairy Technol. 15:261-274.

Beauchemin, K. A., W. Z. Yang, and L. M. Rode. 2003. Effects of particle size of alfalfa-based dairy cow diets on chewing activity, rumen fermentation, and milk production. J. Dairy Sci. 86:630-643.

Belyea, R. L., F. A. Martz, and G. A. Mbagaya. 1989. Effect of particle size of alfalfa hay on intake, digestibility, milk yield, and ruminal cell wall of dairy cattle. J. Dairy Sci. 72:958-963.

Calberry, J. M., J. C. Plaizier, M. S. Einarson, and B. W. McBride. 2003. Effects of replacing chopped alfalfa hay with alfalfa silage 
in a total mixed ration on production and rumen conditions of lactating dairy cows. J. Dairy Sci. 86:3611-3619.

DeVries, T. J., M. A. G. von Keyserlingk, D. M. Weary, and K. A. Beauchemin. 2003. Measuring the feeding behavior of lactating dairy cows in early to peak lactation. J. Dairy Sci. 86:3354-3361.

Fahey, G. C., and L. L. Berger. 1988. Carbohydrate nutrition of ruminants. Pages 269-279 in Ruminant Animal Digestive Physiology and Nutrition. Prentice Hall, Englewood Cliffs, NJ.

Grovum, W. L., and V. J. Williams. 1973. Rate of passage of digesta in sheep. 4. Passage of marker through the alimentary tract and the biological relevance of rate-constants derived from the changes in concentration of marker in faeces. Br. J. Nutr. $30: 313-329$.

Heinrichs, A. J., D. R. Buckmaster, and B. P. Lammers. 1999. Processing, mixing, and particle size reduction of forages for dairy cattle. J. Anim. Sci. 77:180-186.

Johnson, L., J. H. Harrison, D. Davidson, J. Robutti, M. Swift, B. Mahanna, and K. Shinners. 2002. Corn silage management. I. Effects of hybrid, maturity, mechanical processing on chemical and physical characteristics. J. Dairy Sci. 85:833-853.

Kononoff, P. J., and A. J. Heinrichs. 2003a. The effect of reducing alfalfa haylage particle size on cows in early lactation. J. Dairy Sci. 86:1445-1457.

Kononoff, P. J., and A. J. Heinrichs. 2003b. The effect of corn silage particle size and cottonseed hulls on cows in early lactation. J. Dairy Sci. 86:2438-2451.

Kononoff, P. J., A. J. Heinrichs, and H. A. Lehman. 2003. The effect of corn silage particle size on eating behavior, chewing activities, and rumen fermentation in lactating dairy cows. J. Dairy Sci. 86:3343-3353.

Krause, K. M., D. K. Combs, and K. A. Beauchemin. 2002. Effects of forage particle size and grain fermentability in midlactation cows. II. Ruminal pH and chewing activity. J. Dairy Sci. 85:1947-1957.

Lammers, B. P., D. R. Buckmaster, and A. J. Heinrichs. 1996. A simple method for the analysis of particle sizes of forage and total mixed rations. J. Dairy Sci. 79:922-928.

Leonardi, C., and L. E. Armentano. 2003. Effect of quantity, quality, and length of alfalfa hay on selective consumption by dairy cows. J. Dairy Sci. 86:557-564.
Mertens, D. R. 1997. Creating a system for meeting the fiber requirements of dairy cows. J. Dairy Sci. 80:1463-1481.

National Research Council. 2001. Nutrient Requirements of Dairy Cattle. 7th rev. ed. Natl. Acad. Sci., Washington, DC.

Plaizier, J. C. 2004. Replacing chopped alfalfa hay with alfalfa silage in barley grain and alfalfa-based total mixed rations for lactating dairy cows. J. Dairy Sci. 87:2495-2505.

Rode, L. M., W. Z. Yang, and K. A. Beauchemin. 1999. Fibrolytic enzyme supplements for dairy cows in early lactation. J. Dairy Sci. 82:2121-2126.

SAS Institute. 1996. SAS User's Guide. Statistics, Version 7 ed. SAS Institute, Inc., Cary, NC.

Schwab, E. C., R. D. Shaver, K. J. Shinners, J. G. Lauer, and J. G. Coors. 2002. Processing and chop length effects in brown-midrib corn silage on intake, digestion, and milk production by dairy cows. J. Dairy Sci. 85:613-623.

Smith, K. A., and M. A. Tabatabai. 2004. Automated instruments for the determination of total carbon, hydrogen, nitrogen, sulfur, and oxygen. Pages 235-282 in Soil and Environmental Analysis Modern Instrumental Techniques. 3rd ed. K. A. Smith and M. S. Cresser, ed. Marcel Dekker, Inc., New York, NY.

Udén, P., P. E. Colucci, and P. J. Van Soest. 1980. Investigation of chromium, cerium, and cobalt as markers in digesta. Rate of passage studies. J. Sci. Food Agric. 31:625-632.

Van Soest, P. J., J. B. Robertson, and B. A. Lewis. 1991. Methods for dietary fiber, neutral detergent fiber and non-starch polysaccharide in relation to animal nutrition. J. Dairy Sci. 74:35833597.

Weatherburn, M. W. 1967. Phenol-hypochlorite reaction for determination of ammonia. Anal. Chem. 39:971-974.

Yang, W. Z., and K. A. Beauchemin. 2002. Optimizing particle size of dairy cow diets with a Penn State Particle Separator. Adv. Dairy Technol. 14:351.

Yang, W. Z., K. A. Beauchemin, and L. M. Rode. 2001. Effects of grain processing, forage to concentrate ratio, and forage particle size on rumen $\mathrm{pH}$ and digestion by dairy cows. J. Dairy Sci. 84:2203-2216. 